\title{
MIDAS
}

Museus e estudos interdisciplinares

9 | 2018

Varia

\section{Life canvas: biological illustration as biographical evidence of illustrators' and researchers' careers}

Telas de vida: ilustração biológica como evidência biográfica da carreira de ilustradores e de investigadores

\section{Simão Mateus e Cristiana Vieira}

\section{OpenEdition}

\section{Journals}

\section{Edição electrónica}

URL: http://journals.openedition.org/midas/1436

DOI: $10.4000 /$ midas. 1436

ISSN: 2182-9543

\section{Editora:}

Alice Semedo, Paulo Simões Rodrigues, Pedro Casaleiro, Raquel Henriques da Silva, Ana Carvalho

\section{Refêrencia eletrónica}

Simão Mateus e Cristiana Vieira, « Life canvas: biological illustration as biographical evidence of illustrators' and researchers' careers », MIDAS [Online], 9 | 2018, posto online no dia 25 janeiro 2018, consultado no dia 19 abril 2019. URL : http://journals.openedition.org/midas/1436 ; DOI : 10.4000/ midas. 1436

Este documento foi criado de forma automática no dia 19 Abril 2019.

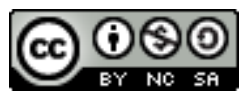

Midas is licensed under a Creative Commons Attribution-NonCommercial-ShareAlike 3.0 International License 


\title{
Life canvas: biological illustration as biographical evidence of illustrators' and researchers' \\ careers
}

\author{
Telas de vida: ilustração biológica como evidência biográfica da carreira de \\ ilustradores e de investigadores
}

Simão Mateus e Cristiana Vieira

\section{NOTA DO EDITOR}

Artigo recebido a 15.03.2017

Aprovado para publicação a 13.01.2018

\section{Introduction}

1 Within the several museum functions (such as preservation, storage, research, exhibition or outreach) performed by academic or professional staff, scientific illustrations play a relevant task in the museum setting and in scientific dissemination. Scientific illustrations represent epistemological and pedagogical outputs (Milach et al. 2015; Salgado et al. 2015). They can illustrate an article, enlarge a small object in a showcase, contextualize or restore an object lost features (e.g. dinosaur drawing - an animal never seen, to illustrate a new fossil specimen, usually incomplete and broken, or a plant with all the organs presented, such as flowers, fruits, summer leaves, or winter branches, when normally they are subsequent, and not seen at same time). On the other hand, a scientific illustration might be an artwork produced using several techniques, either by an amateur or a professional with scientific skills in observation and illustration (Marques 2013). The curatorship of museum's illustrations, depicting their origins and authors, might become 
a difficult task, especially when little is known about these professionals/artists or objects. Therefore, scientific illustrations are culturally mediated constructions, which existence is determined by personal and professional trajectories of their illustrators, but also by the organizational and historical contexts, which remain is most cases unknown unless there is a specific approach in this regard. In this context, this article demonstrates the relevance of pursuing such studies focusing on biological illustration as biographical evidence of illustrators and researchers' careers.

2 In this framework, by cataloguing and characterizing the scientific biological illustrations of the Natural History and Science Museum of the University of Porto collections (MHNCUP), we draw attention to its origin, their illustrators and relations with other museums and actors within the Porto University, so that the lack of information and links might arise, considering also that scientific illustrations are a multidisciplinary source of many academic fields, including heritage and museum studies (Pyle 2000; Reis, Guerra, and Braga 2006; Hodges 1989; Marques 2017).

\section{Historical perspective}

\section{Early basis of drawing classes}

3 Drawing classes were an early curriculum component in the Schools that preceded the origin of the University of Porto. In the period between 1762 and 1803, the "Nautical Class" was the platform for the training of navy captains and lieutenants in the city of Oporto that around 1779, instructed with a mandatory "Drawing and Sketch Class" of maps, machines and navy constructions. These two classes were the basis of the foundation of the Royal Academy of Marine and Commerce of Porto (1803-1837) and the succeeding Porto Polytechnic Academy (1837-1911) (Lopes 1915; Santos 2011). In these institutions, drawing classes were considered a condition of admission for students applying to the Preparatory Engineering program at the School of the Army and to the Preparatory Course program at the Naval School. At the Porto Polytechnic Academy, Francisco da Silva Cardoso, Guilherme António Correia (1829-1901), António da Silva (1850-1893), Vieira Portuense (1765-1805), Domingos António Sequeira (1768-1837), João Baptista Ribeiro (1790-1868), Raimundo Joaquim da Costa (1778-1862), Augusto Roquemont (1804-1852), and José Teixeira Barreto (1782-1810) were some of teachers associated to these drawing classes (Santos 2011). With three weekly lessons of two hours each, drawing lessons were mandatory in the $1^{\text {st }}, 2^{\text {nd }}$ and $3^{\text {rd }}$ years of the programs. Naturally, the drawing taught in this period was mainly technical, such as "Nautical Drawing", "Drawing of Figure, Landscape and Ornate", "Architectural Drawing", and "Topographical and Machine Drawing". The importance given to the ability to draw is noteworthy, since two of the 12 pecuniary prizes awarded to the most distinguished students were attributed to drawing class (Lopes 1915; Santos 2011).

\section{Scientific and biological illustration classes}

4 With the shift of the political regime in Portugal, the institution of a Republic and its ideals led to the conversion of the Polytechnic Academy into a University, with several Faculties, in 1911. With the restructuring of the programs, the Drawing course for the students of the Science Faculty was divided into "Rigorous Drawing", "Drawing of 
Machines", “Topographical Drawing", "Drawing Applied to Cartography", and "Drawing in Sight of Plants and Animals". In the collection of the Natural History and Science Museum of the University of Porto, international manuals acquired by the earlier professors of the drawing classes to support the teaching of biological drawing are still available (e.g. L'Art Élémentaire, published for the first time in 1879, by Armand Cassagne and sold as a collection of drawing supporting material "Ch. Fouraut et Fils, Éditeurs, Rue Saint-André-des-Arts, no 47, à Paris).

5 The "Drawing in Sight of Plants and Animals" course, included in the section of Natural History Sciences, was first taught by Alves Bonifácio (1860-1943) in 1911-1912 and later on by Paulo Ferreira in 1912-1918. Between 1946 and 1962, the teachers in charge of "Drawing Applied to Biological Sciences", were António Lima Fernandes de Sá and Guilherme Rica Gonçalves (1919-2011). It is also interesting to mention that the content of the course labelled "Applied Drawing to Biological Sciences", published in the Yearbook of Science Faculty for the academic year 1950-51, is presented in great detail (Gonçalves 1952). The content is extensive and includes teaching the value of Drawing and Illustration (a) as a valuable element in creating and developing the spirit of observation; (b) for attention orientation and memory retention; (c) for scientific probity; (d) to restore the admiration of Nature; (e) as a pedagogical instrument; ( $\mathrm{f}$ ) as a scientific information and documentation tool. The content of this course mentions the techniques taught and the materials applied, which included chalk drawing on blackboards, pencil drawings and pen and ink illustrations, as well as the illustration of macroscopic or microscopic structures, schematic and semi-schematic drawing, the use of microphotographic cameras or projectors as valuable aids for scientific illustration, or the reproduction of prints and printed texts.

6 It is known that until the beginning of the 70s of the twentieth century, the Biological Drawing course existed autonomously and that after April $25^{\text {th }} 1974$, with the frequent transformations in Biology programs' curriculum, drawing became an applied, but not taught, skill practiced in some experimental classes of the program (e.g. Plant Anatomy classes).

\section{Biological illustrations}

7 It is worth mentioning that in this period photographic cameras were inexistent, too expensive or demanded several heavy cases with equipment, therefore, skills in illustration were most welcome in a student, a researcher, a technician or a scientist's profile, that often accumulated the functions of a naturalist and a illustrator. Biological illustration, usually the drawing of a set of characters helping to diagnose the identity of an animal, a plant, a fossil, a cell, or any other biological entity, became a tool widely used in natural history museums for communication, and teaching the ability to observe and question the natural world that surrounded us (Bruzzo 2004).

8 An illustration provides not only information about the drawn entity, but also information on the illustrator's skills, techniques or drawing maturity. On the other hand, the drawings of a researcher reveal his/her learning evolution, methodology and areas of interest throughout the illustrator's career. Therefore, an illustration remains a biographical object, in the same way a scientific article or a piece of artwork does.

The investment of some universities in illustration classes, or even in the employment of illustrators, was very relevant until the $20^{\text {th }}$ century. Meanwhile, for the last decades of 
the twentieth century, with the technical improvements and mass production of the photographic camera, these instruments became affordable, lighter and the revelation process less expensive (Bruzzo 2004). Consequently, photographs of scientific objects became massively used by all University departments and publications. Nowadays, photographs are the common observation evidence for scientific papers and books, accompanying hand illustrations, which became more specific of iconographies or special, somewhat expensive, editions. Biological illustration lost its status as an essential skill in students and researchers, and became a personal artistic quality, despite remaining a remarkable and desirable feature in a researcher or biology professional.

\section{Methods}

10 This research was motivated by the curatorship for an exhibition prepared for the library of the Science Faculty of Oporto University (Science in an Illustration - opened March 2016). This exhibition was organized with the support of the Natural History and Science Museum of Oporto University (MHNC-UP). After some standard analysis of the museum illustration collections, all the authors of biological illustrations and publications outputs were inventoried, achieving an organized images database. From this database, we listed all the authors of the artworks and concluded that they correspond to a very limited number of highly skilled, but quite unknown, illustrators associated with the Museum. Among them is Sara Cabral Ferreira, Paulo Ferreira (1867-1936), Alice Beatriz de Lemos Pereira, Jaime G. Cibrão, Augusto Pereira Nobre (1865-1946) and Joaquim Sampaio (1899-1981).

11 On April $20^{\text {th }}$ of 1974, a fire in the building, where the Museum and the Science Faculty were located, destroyed some of the University archives and documents that contained a significant part of the institution's contractual history. Therefore, some of the primary sources that would be relevant for this study are no longer available. Nevertheless, in order to undertake this study, we collected data in the museum archival documentation, including notes found in publications (prefaces and acknowledgements sections), examining academic relationships, and analysing illustrations with original pencil hand notes by their authors. Furthermore, we contextualize these $20^{\text {th }}$ century illustrators' activities on the illustration/drawing activities and classes in Porto University history, until the extinction of biological illustration classes and illustrator's professional contracts, nearly 50 years later. As far as we know, this is the first time that such an approach is presented concerning the skills and professional biographical information of the illustrators associated with the MHNC-UP collections.

\section{Results}

During the first half of the $20^{\text {th }}$ century, when the Faculty of Sciences of the University of Porto (FCUP), the Natural History Museum of the University of Porto, the Science Museum of the University of Porto and the Botanical and Zoological Institutes co-existed in the same building, their activities intertwined in a dense contact of individuals and careers. Many of the original scientific illustrations of the works published by researchers and professors of the Science Faculty (many of which were staff or collaborated with the Natural History Museum) were carried out either by professionals or by these researchers and professors. In the course of time, and after being published in papers, manuals, books 
or iconographies published by the Science Faculty or by the Natural History Museum, the original illustrations became part of the Natural History and Science Museum collections.

\section{Illustration as an illustrator's professional output}

Between 1919 and 1974, the personnel hired as illustrators belonged to the Biological Sciences Section of the Science Faculty, and their contracts can still be found in official documents of the University of Porto. These documents prove the hiring of at least three illustrators for the "Biological Sciences Section": Sara Cabral Ferreira, Paulo Ferreira and Justino Pinto de Oliveira. Furthermore, as early as 1948, the Yearbooks of the FCUP state that, in the Technical and Auxiliary Staff of the Zoology and Anthropology Group, the $2^{\text {nd }}$ Class Illustrator hired was Alice Beatriz de Lemos Pereira. These illustrators were not exactly museum professionals, but FCUP hired personnel with the main purpose of producing biological illustrations. Nevertheless, eventually, they served the purpose of illustrating both living organisms and taxidermied/herborized specimens of the Museum studied by the FCUP researchers, who were, at the same time, professors, museum directors and/or conservators.

4 Unfortunately, and despite our efforts in consulting Conservatory databases, without full names of some of the illustrators, we could not find more biographical data than what is presented, but we aim to continue researching for more details on the illustrators' identities.

5 In the archives of the MHNC-UP there are several illustrations signed by Sara Cabral Ferreira, some of them dated from 1914 and 1916. In spite of the abundance of other sets of illustrations, the support information is scarce. It is known that Sara Cabral Ferreira was an illustrator hired by the "Biological Sciences Section" of the FCUP in 1919, and that she died around 1927. There are no records of her enrolment as a student either at the Polytechnic Academy or at the FCUP. Little is known about this illustrator, but the originals of her illustrations show a very rapid evolution and increasing dominance of black and white drawing techniques both in the works of Zoology and Botany. Sara Cabral Ferreira extensively illustrated specimens of the Zoological Museum and also of the Herbarium collection, probably as a requirement for the publication of two massive publication series undertaken by Augusto Nobre about Portuguese Marine biodiversity and Gonçalo Sampaio concerning Botanic diversity (Figure 1 - from 1 to 8). In all the publications that include her illustrations, authors or editors emphasized, in the prefaces, the early loss of an excellent illustrator, her artistic talent and the scientific value of her illustrations (Nobre 1931b; Sampaio 1949).

16 From her known original artwork, the maximum exponent Sara Ferreira's technique is revealed in the works of echinoderms, done in monochromatic sepia tones. However, her first works, dated from 1914/1916, of aquatic fauna, mostly microscopic, were already very promising. This illustrator frequently signed the originals as "Sara Ferreira", or with a stylized "SF", but many publications do not show her signature, despite her authorship being mentioned. 


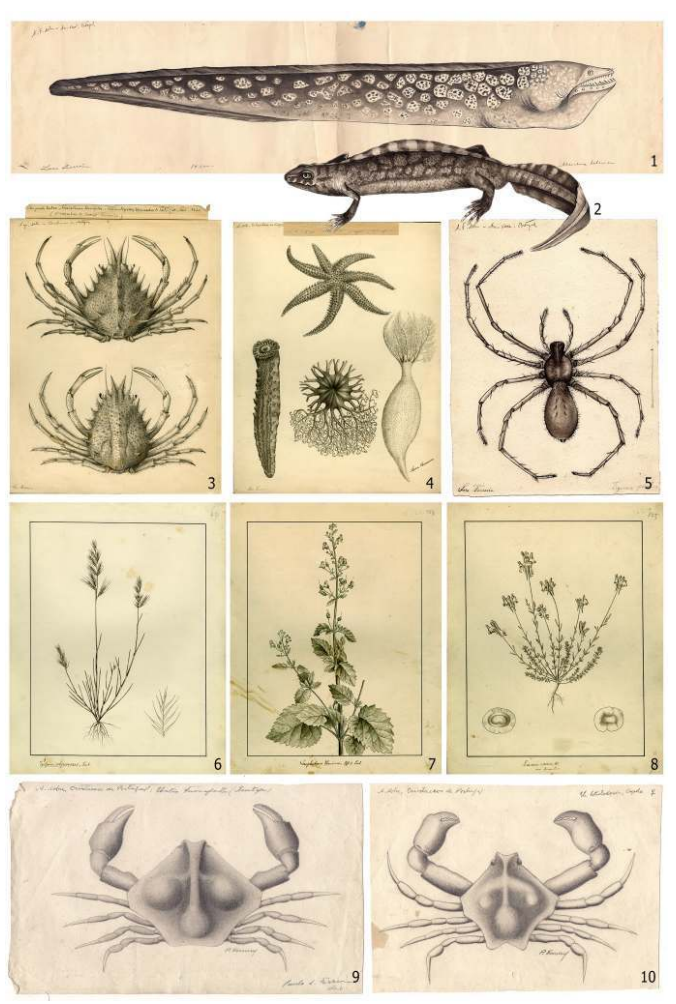

Fig. 1 - Sara Cabral Ferreira and Paulo Ferreira illustrations. Images 1 to 8: illustrations by Sara Cabral Ferreira scanned from originals with handwritten notes. 1. Mediterranean moray (Muraena helena Lineu, 1758), (Nobre, A. 1935), Est. 54; 2. Marbled newt (Triturus marmoratus Latreille, 1800); 3. " Crustaceans from Portugal" (Nobre 1931a, 1936); 4. "Echinoderms of Portugal" (Nobre 1931b); 5. Spider (Tegenaria parietina Fourcroy, 1785). Images 6 to 8: flora illustrations by Sara Cabral Ferreira published in Selective Iconography of the Portuguese Flora by Gonçalo Sampaio (1949). 6. Vulpia alopecurus Link; 7. Scrophularia herminii Hoffmanns \& Link, 1813; 8. Linaria caesia DC. var. decumbens. Images 9 to 10: illustrations by Paulo Ferreira scanned from originals with handwritten notes, published in Crustaceans of the Portugal (Nobre 1931a; 1936). 9. Ebalia tumefacta Montagu, 1808 Fig 71 (Nobre 1931a); 10. Ebalia deshayesi Lucas, 1846 (synonym of Ebalia setubalensis Capello 1876), fig. 72 (Nobre 1931a), Est. 27 (Nobre 1936).

(c) MHNC-UP IIlustrations: UP-MHNC-IC-001 to UP-MHNC-IC-010

Paulo Ferreira (1867-1936) was an engineer, a PhD mathematician and the teacher of "Rigorous Drawing", "Drawing of Machines" and "Topographical Drawing" at the University since 1912. Despite his advanced skills in non-biological illustration, he was professionally responsible for some animal illustrations, such as crustacean (Figure 1 from 9 to 10), always signing by "Paulo Ferreira". Few biological drawings are known by Paulo Ferreira, and they demonstrate a relatively lower detail quality, a circumstance that might be explained by the fact that Paulo Ferreira was not dedicated exclusively to biological drawing, and was probably more experienced in technical drawing.

Alice Beatriz de Lemos Pereira had a long career as a researcher in biology, but also as an illustrator, contractually associated with the FCUP. Her first illustrations date back to 1933, when she belonged to the Association of Natural Philosophy. This Association was created by the FCUP students with the purpose of promoting scientific exchange, the active participation of students in research, and in the works carried out by the FCUP professors, as well as assisting the organization of zoological, botanical and mineralogical collections. This Association also promoted a series of publications, by volumes, under the title of Works of the Association of Natural Philosophy. In the first volume of this publication, 
Alice Pereira, still a student, published her first article, «Study of the Zebras», signing two illustrations - a couple of maps of the African continent.

Sometime before 1946, and probably after a request by Américo Pires de Lima (1886-1966), Alice Pereira worked on at least two illustrations for the publication Flora Portuguesa, in which several other plates of unknown authorship with botanical diagrams help taxonomic characters' diagnostic, along with 13 illustrations of plant species by Sara Cabral Ferreira (Sampaio 1946). Later on, when she was already listed as Technical and Auxiliary Staff of the Zoology and Anthropology Group as the $2^{\text {nd }}$ Class Illustrator, Alice Pereira, illustrated the dissertation The Stoechas Gingins Section of the 'Lavandula' Linn Gender (Rozeira 1949), which Arnaldo Deodato Rozeira presented to apply for the position of extraordinary professor of the $2^{\text {nd }}$ group - Botany of the FCUP.

There is not much information about the original works of Alice Pereira, and the published illustrations or typographic plates, already very clean, barely reflect any biographical technical details. This illustrator signed as "Alice de Lemos Pereira" or "Alice Lemos Pereira".

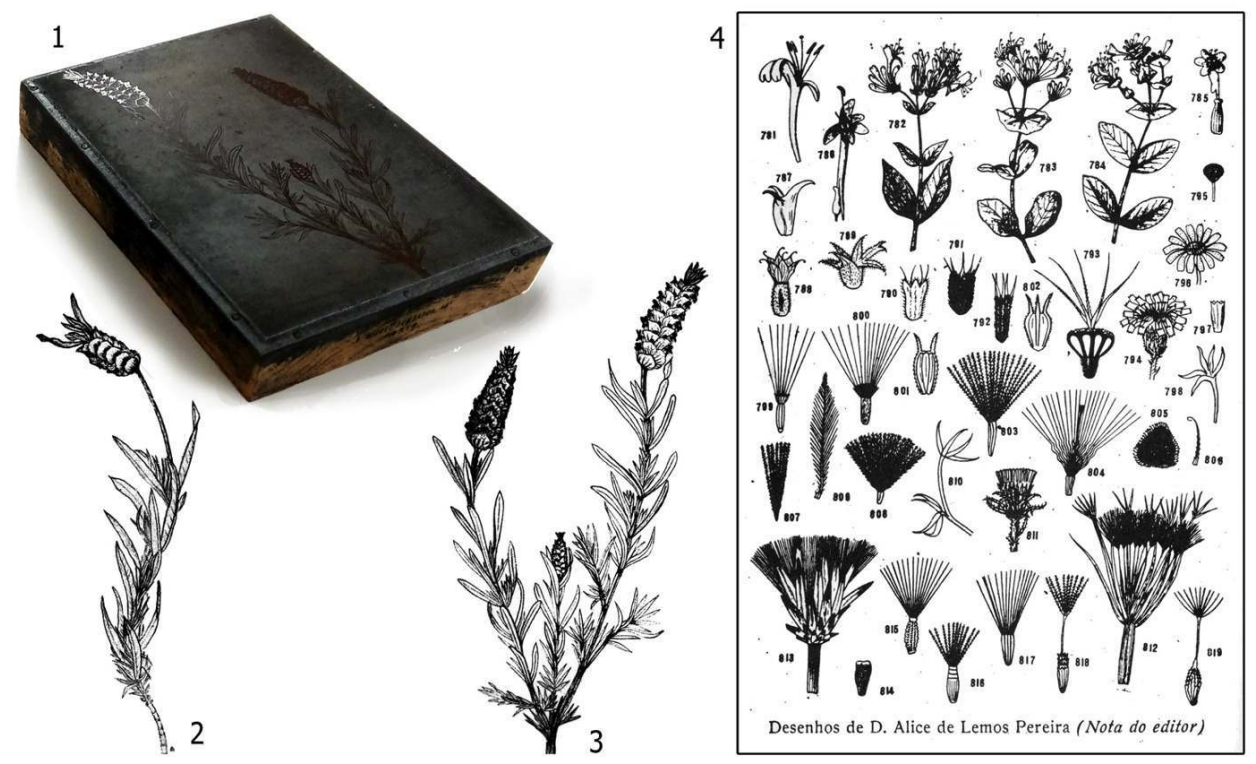

Figure 2 - Illustrations by Alice de Lemos Pereira obtained from published works or off-set metal plates of lavender (Lavandula spp, Secção Stoechas). 1. Off-set metal plate of a lavander species ( Lavandula Stoechas subsp. atlantica Br.-BI.); 2. Est. XXXI: published illustration of Lavandula Stoechas subsp. atlantica Br.-Bl; 3. Est. XXIX: published illustration of Lavandula Stoechas subsp. Linneana var. luisieri nov. var. (Rozeira 1949); 4. Illustrations of diagnostic characters of the Asteraceae Family (Fam. 131) published in Sampaio (1946).

(c) MHNC-UP IIlustrations: UP-MHNC-IC-011 and UP-MHNC-IC-012

\section{Illustration as evidence of an untraceable illustrator}

João Alves dos Reis Júnior (1871-?), a self-taught naturalist, devoted himself to bird taxidermy donating countless specimens to the Polytechnic Academy and later, the Natural History University collections. In 1926, he officially began his long scientific career linked to the University Zoological Museum (part of the Natural History Museum), for which he was hired as a conservator. From his unceasing work as an ornithologist resulted the Systematic and Analytical Catalog of the Birds of Portugal (Reis Júnior 1931), the first great annotated inventory of the national bird fauna, widely illustrated by Jaime $\mathrm{G}$. 
Cibrão, an illustrator whose biography and professional career remain unknown to this day (see figure 3). His illustrations were based on taxidermied specimens, and were typically placed in an "artificially-natural background" alluding to the natural habitat of the illustrated bird.

Although we can only identify the existence of undated ornithological illustrations from Jaime G. Cibrão using trace technique, one may argue that they are all from the same time, due to the uniformity of the drawing technique and the illustration style. His signature varies in handwritten style but always keeping "J.G.Cibrão" in close proximity or immersed into the drawing's body.
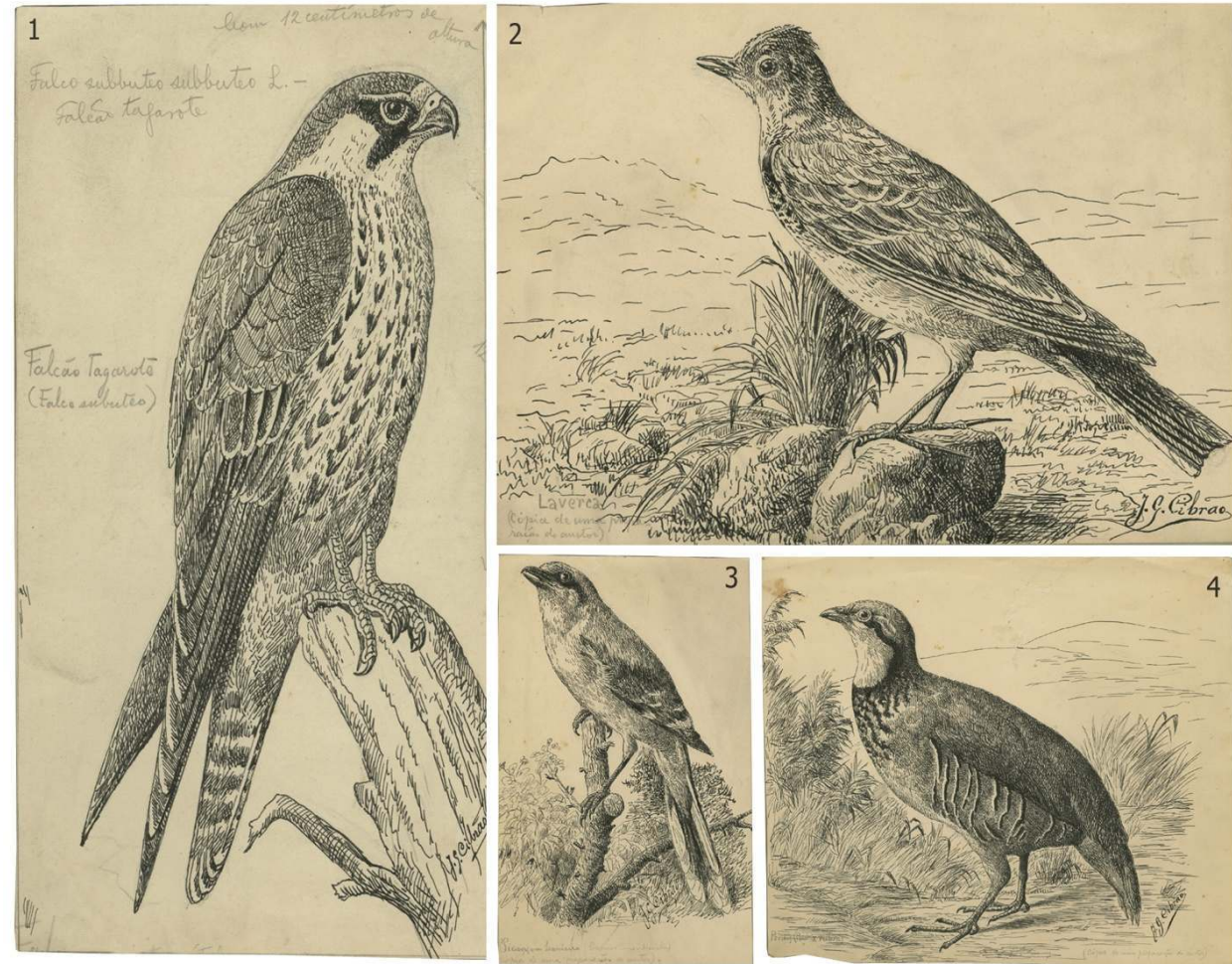

Figure 3 - Illustrations by Jaime G. Cibrão. Scanning of originals with handwritten notes published in Reis Júnior (1931). 1. Eurasian hobby (Falco subbuteo Lineu, 1758); 2. Eurasian skylark (Alauda arvensis Lineu, 1758); 3. Southern grey shrike (Lanius meridionalis Temminck, 1820); 4. Red-legged partridge ( Alectoris rufa Lineu, 1758).

(c) MHNC-UP IIlustrations: UP-MHNC-IC-013 to UP-MHNC-IC-016

\section{Illustration as evidence of a researcher's multi-skilled profile}

In the history of the Polytechnic Academy and the University of Porto, some researchers were recognized because of their prolific work in several fields - they excelled as professors, researchers and museum creators/promoters, but despite of all these roles, they still accomplished massive series of publications regarding Portuguese biodiversity throughout their careers. The illustration of their works was performed either by professional illustrators, or if they were not available, the task was taken on by themselves, allowing the development of their illustration skills to serve their purpose. The most renowned of these cases was the founder and director of the Zoological Museum, Augusto Pereira Nobre (1865-1946). 
As a student, Augusto Pereira Nobre began his zoological research, and in 1901, when he was appointed as an effective naturalist of the Academy, he continued with the organization of the Museum of Zoology, conducting practical courses. From 1984 to 1942 he also illustrated his own papers, published in the yearbooks of the Academy in the Annaes de Ciencias Naturaes, a publication series that he created, as well as in various book volumes about the Portuguese invertebrate and vertebrate fauna.

The most common illustrations by Augusto Pereira Nobre are of the schematic type: gastropods, fish, and molluscs. However, many detailed and shaded illustrations of some species are also known (Figure 4). His works were also illustrated by Sara Cabral Ferreira and Paulo Ferreira, who depicted fresh or preserved specimens of the Museum (Figure 1). Most of the works of Augusto Pereira Nobre were executed with the technique of stippling and outlines. In addition, the Museum's archive also includes several watercolours of very good quality. He used the acronym "AN" (or "A. Nobre") in the drawing area to be included in the typographic board, without ceasing to sign and date the same illustration at the bottom of the drawing sheet.

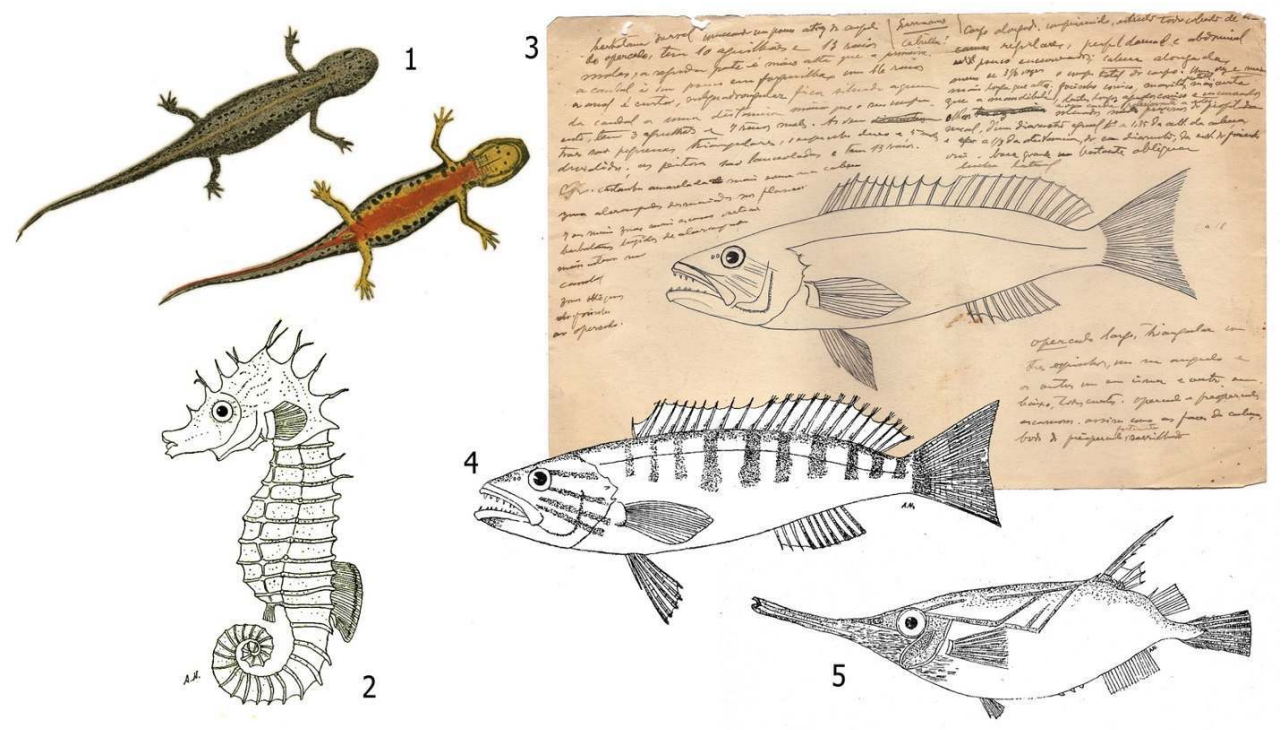

Figure 4 - Illustrations by Augusto Pereira Nobre. 1. Published drawing of a newt Lissotriton boscai Lataste, 1879 Est. I (Nobre 1909-12); 2. Published illustration of long-snouted seahorse fish Hippocampus guttulatus Couvier, 1829, Est. 41 (Nobre 1935); 3. Original sketch of Comber, Serranus cabrilla Linnaeus, 1758 with hand notes; 4. Published illustration of Comber, Serranus cabrilla Linnaeus, 1758 Est. 3 (Nobre 1935); 5. Published illustration of Longspine snipefish, Macroramphosus scolopax Linnaeus, 1758 (synonym: Centriscus scolopax) Est. 40 (Nobre 1935)

(c) MHNC-UP IIlustrations: UP-MHNC-IC-017 to UP-MHNC-IC-020

\section{Illustration as evidence of microscopic worlds research}

The acclaimed botanist Gonçalo Sampaio (1865-1937), was one of the first teachers to introduce the course of experimental botany with a complete practical content (published in 1911), which included not only observation and illustration of cellular structures by Biological Sciences students, but also experimenting "Microphotography" of histological plant structure in a laboratory. Although we know that Gonçalo Sampaio registered in a very detailed way all his research, he did not draw much, with the exception of the frequent schematic illustrations of microscopic structures, presented in the identification notes placed in the herbarium specimens (Figure 5, image 1). 
Gonçalo's son, Joaquim Sampaio (1899-1981), soon accompanied his father in many botanical excursions, also becoming an enthusiastic collector and naturalist in Porto's Institute of Botany. His academic research, especially after his father's death, was mostly focused in Phycology, and he profusely illustrated his publications of microscopic algae with numerous plates of microscopic specimens. These plates were obtained with a camera lucida device linked to a microscope, performing the drawing of a microscopic specimen present in the slide in a very enlarged scale (Figure 5 , from 2 to 3 ).
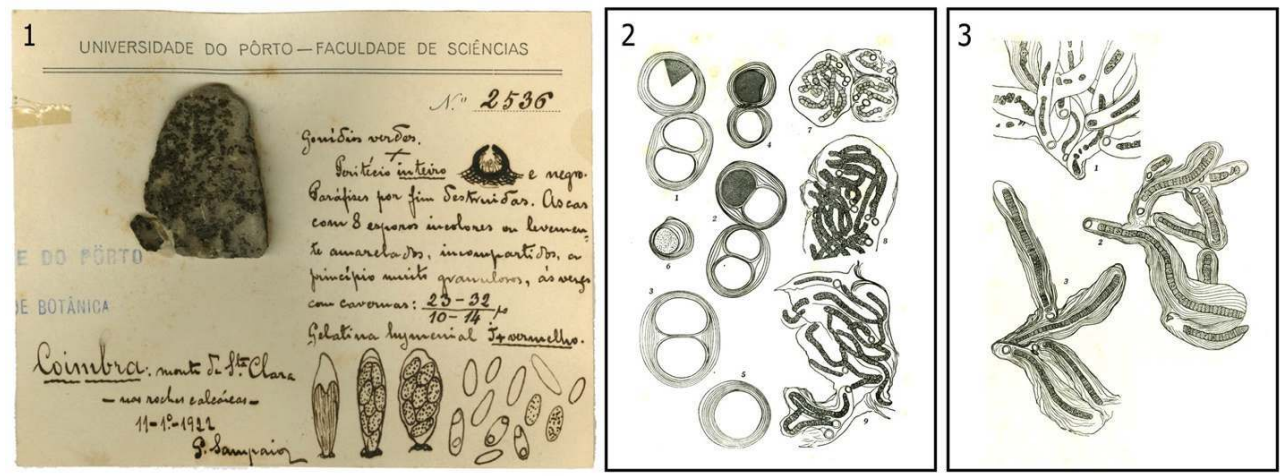

Figure 5 - Illustrations by Gonçalo Sampaio and Joaquim Sampaio. 1. Label of microscopic reproductive structures of the lichen Verrucaria carrisoi Samp. with illustrations and hand notes by Gonçalo Sampaio (specimen PO 2536L); Images 2 to 3. Scanning of publishing proofs of Cianófitas da Flora Portuguesa drawings by Joaquim Sampaio (1959); 2. Est. IV: Chroococcus turgidus (Kütz) Näg. (left) and Scytonema crustaceum Ag. (right); 3. Est. V. Scytonema crustaceum Ag.

(c) MHNC-UP IIlustrations: UP-MHNC-IC-021 to UP-MHNC-IC-022

\section{Conclusion}

The original illustrations currently belonging to the MHNC-UP collections were most frequently produced by the staff of the Science Faculty or the Natural History Museum, or by some researchers and teachers during the first half of the $20^{\text {th }}$ century. These originals are, in some cases, unique links to the works and relationships between unknown artists, museum professionals, researchers and teachers, corresponding to rare evidences of their careers.

The curatorship of original biological illustrations of the MHNC-UP has revealed not only unknown illustrators under contract, but also the interest, skills and active role that some remarkable researchers had on the illustration process of many of the University's iconographies and scientific publications. This authorship meta-analysis allowed the identification of the characteristic drawing style and signatures of researchers such as Augusto Pereira Nobre or Gonçalo Sampaio, but also some illustrators lost in the oblivion of time, such as Sara Cabral Ferreira, Jaime G. Cibrão, Paulo Ferreira and Alice Beatriz de Lemos Pereira, of whom we still have little biographical information. For that reason it remains pertinent to continue this research in order to achieve a better understanding of illustrator's trajectories and their connections to the university and the museum, contributing to their history and knowledge. 


\section{BIBLIOGRAFIA}

Bruzzo, Cristina. 2004. "Biologia: Educação e Imagens. " Educação e Sociedade 25 (89): 1359-1378.

Gonçalves, Firmino Maria 1952. Anuário da Universidade do Porto: Ano Escolar de 1950-1951. Vol. VI, Anuário VI. Porto: Tip. e Enc. Domingos de Oliveira.

Hodges, Elaine R. S. 1989. "Scientific Illustration: A Working Relationship Between the Scientist and Artist.” BioScience 39 (2): 104-111.

Lopes, Eduardo. 1915. “Genealogia duma Escola: Origem e Tradições da Academia Politécnica, Actual Faculdade de Sciências da Universidade do Porto (1762-1911)." In Anuário da Faculdade de Sciências da Universidade do Porto, Antiga Academia Politécnica. Anos Lectivos de 1911-1912 a 1913-1914, V-LX. Coimbra: Imprensa da Universidade.

Marques, Diana. 2013. "Desenhar a Ciência, Saber o que se Desenha." Ciclo de Conferências Desenhar, Saber Desenhar, Faculdade de Belas Artes da Universidade de Lisboa. http://

www.dianamarques.com/Downloads/DMarques-DesenharCiencia.pdf

Marques, Diana. 2017. "Scientific Illustration overview." In Image in Science and Art, ed. O Pombo, 175-182. Lisbon: Fim de Século.

Milach, Elisa Machado, Maria Cristina dos Santos Louzada, Ruhena Kelber Abrão Ferreira, and José Eduardo Figueiredo Dornelles. 2015. “A Ilustração Científica como uma Ferramenta Didática no Ensino da Botânica." Acta Scientiae 17 (3): 672-683.

Nobre, Augusto. 1909-12. "Batrachios." In Fauna Aquicola de Portugal. Extracto do Boletim da Direcção Geral da Agricultura, anno IX, n. 04.

Nobre, Augusto. 1931a. Crustáceos Decápodes e Stomatópodes Marinhos de Portugal. Edited by Instituto da Zoologia da Universidade do Pôrto. Porto: Impr. Portuguesa.

Nobre, Augusto. 1931b. Echinodermes de Portugal. Porto: Instituto de Zoologia da Universidade do Porto.

Nobre, Augusto. 1935. Fauna Marinha de Portugal. I - Vertebrados (Mamiferos, Repteis e Peixes). [s.n.]: Porto.

Nobre, Augusto. 1936. “IV - Crustáceos Decápodes e Stomatópodes Marinhos de Portugal.” In Fauna Marinha de Portugal. Porto.

Pyle, Cynthia M. 2000. “Art as Science: Scientific Illustration, 1490-1670 in Drawing, Woodcut and Copper Plate." Endeavour 24 (2): 69-75.

Reis Júnior, João Alves dos. 1931. Catálogo Sistemático e Analítico das Aves de Portugal. Porto: Araújo \& Sobrinhos e Sucessores.

Reis, José Claudio, Andreia Guerra, and Marco Braga. 2006. "Ciência e Arte:

Relações Improváveis?" História, Ciências, Saúde-Manguinhos vol 13 (Oct.): 71-87.

Rozeira, Arnaldo. 1949. “A Secção Stoechas Gingins do Género Lavandula Linn.” Brotéria-Ciências Naturais 18: 5-84. 
Salgado, Pedro, Joana Bruno, Mafalda Paiva, and Xavier Pita. 2015. “A Ilustração Científica como Ferramenta Educativa." Interacções 11 (39): 381-392.

Sampaio, Gonçalo. 1946. Flora Portuguesa. 2. edição. Porto: Imprensa Moderna.

Sampaio, Gonçalo. 1949. Iconografia Selecta da Flora Portuguesa. Lisboa: Instituto para a Alta Cultura.

Sampaio, Joaquim. 1959. “Cianófitas da Flora Portuguesa.” In Publicações do Santos, Cândido. 2011. História da Universidade do Porto, Edições Centenário - Série Histórica. Porto: U.Porto Editorial.

\section{RESUMOS}

As ilustrações científicas são um dos resultados do trabalho de investigação, comunicação ou disseminação de um museu de história natural. É comum que, dado o seu papel na representação científica e na sua divulgação junto dos públicos, as ilustrações sejam escolhidas para caracterizar e ocupar grandes áreas das exposições, substituindo informações de texto. No entanto, os autores dessas ilustrações são com frequência desconhecidos do público em geral, assim como dos académicos, e de outros profissionais de museus, tais como taxidermistas, conservadores e bibliotecários que estão implicados na génese de uma exposição. Embora alguns desses autores fossem relativamente bem conhecidos através das ilustrações científicas publicadas, outros permanecem desconhecidos. Neste contexto, evidenciamos alguns ilustradores, porventura, menos conhecidos ou esquecidos do Museu de História Natural e Ciência da Universidade do Porto (MHNC-UP) que foram identificados na documentação histórica associada a várias coleções científicas do MHNC-UP. Entre estes encontram-se: Sara Cabral Ferreira, Paulo Ferreira (1867-1936), Alice Beatriz de Lemos Pereira, Jaime G. Cibrão, Augusto Pereira Nobre (1865-1946) e Joaquim Sampaio (1899-1981). Apresentamos, pela primeira vez, informações sobre estes ilustradores, sublinhando as suas capacidades técnicas, assim como dados relativos às suas biografias profissionais. Para esse efeito recorremos à documentação de arquivo do Museu, incluindo os prefácios e as notas de agradecimentos em publicações, analisando-se não só as relações académicas, como algumas das ilustrações originais contendo anotações a lápis. Além disso, contextualizamos as atividades destes ilustradores nas aulas de ilustração/desenho e no Museu até à extinção das classes de ilustração biológica e dos contratos de ilustrador profissional.

Scientific illustrations are one of the possible outcomes of a natural history museum's research, communication or dissemination efforts. It is common that, given their role in science representation and dissemination, illustrations feature and occupy large areas of exhibition space, replacing text information. However, the authors of these illustrations are frequently unknown to the general public, including academics, but also many other museum professionals, such as the laboratory taxidermists, curators and librarians behind the genesis of an exhibition. Although some science illustrators were relatively well known by their published works, others remain quite unknown. In this context, we highlight unknown or forgotten illustrators of the Natural History and Science Museum of the University of Porto (MHNC-UP) that were identified in the archival documentation associated with the scientific collections of the MHNC-UP. Among them is Sara Cabral Ferreira, Paulo Ferreira (1867-1936), Alice Beatriz de Lemos Pereira, Jaime G. Cibrão, Augusto Pereira Nobre (1865-1946) and Joaquim Sampaio (1899-1981). Information about the skills and the professional biographies of these illustrators is presented for the first time. The data was gathered in the museum archival documentation, including notes found in publications (preface and acknowledgements), examining academic relationships, and analysing illustrations with original pencil hand notes by their authors. Furthermore, we contextualize these 
illustrators' activities with the drawing classes and the Museum, until the extinction of biological illustration classes and professional illustrators contracts.

\section{ÍNDICE}

Keywords: scientific illustration, Natural History and Science Museum of the University of Porto, university collections, scientific collection, history of science

Palavras-chave: ilustração científica, Museu de História Natural e da Ciência da Universidade do Porto, coleções universitárias, coleção científica, história da ciência

\section{AUTORES}

\section{SIMÃO MATEUS}

He is the scientific director and the curator of the Dinosaur Park of Lourinhã and is the former curator of the Palaeontology collection of the Natural History and Science Museum of the University of Porto. He holds two master's degrees (Museology and Palaeontology). He focuses his research on the history of the illustrators of museums. He is also a scientific illustrator. He has participated and organized scientific illustration exhibitions, and has published books for scientific dissemination for children and young adults (both text and illustrations). He is a doctoral candidate in Heritage Studies, specializing in Museology, at the University of Porto. Parque dos Dinossauros da Lourinhã, Rua Vale dos Dinossauros, 25, Abelheira, 2530-059 Lourinhã, Portugal, s.mateus@dinoparque.pt

\section{CRISTIANA VIEIRA}

She is the curator of the Herbarium of the Natural History and Science Museum of the University of Porto since 2015, being responsible for the national and international botanical collections integrated in the Herbarium by researchers and professors associated with the Polytechnic Academy and the Faculty of Sciences of the University of Porto, since the 19th century. As a researcher at the University of Porto she collaborated in works related to the conservation, monitoring and management of Portuguese plant species and habitats. After graduating she furthered her knowledge of taxonomy and ecology of bryophytes and authored publications on botany and science dissemination.

Museu de História Natural e da Ciência da Universidade do Porto (MHNC-UP), Praça Gomes Teixeira, 4099-002 Porto, Portugal, cvieira@mhnc.up.pt 